\title{
Constructing an Islamic Nation: National Mosque Building as a Form of Nation-Building
}

\author{
Annelle R. Sheline \\ Center for the Middle East, Baker Institute for Public Policy, Rice University, Houston, Texas, USA \\ ${ }^{\star}$ Corresponding author. Email: asheline@rice.edu
}

\begin{abstract}
A majority of national mosques were built in the 1980s, 1990s, and early 2000s. Why did national mosque construction become important to Islamic states during this period, when it had not been a priority in earlier decades when many of these states achieved independence? This article suggests that national mosque construction was the result of political elites' anxieties regarding the threat to regime stability posed by Islamist activists. Drawing on a medium $N$ dataset of all 25 states that recognized Islam as their official religion, the article shows that mosque construction increased after 1979 when political elites adopted a strategy of Islamic nation-building, with one expression of this strategy taking the form of national mosque-building in order to visually manifest the regime's religious authority. In addition to medium $N$ analysis, the article uses process tracing to examine national mosque building in three case studies, as well as interview data, to evaluate whether mosque construction achieved the desired effect of bolstering regimes' religious legitimacy in these contexts. The findings have implications for understanding the use of symbolic religious structures as tools for nation-building that have often been overlooked due to the tendency to associate nationalism with secular visions of modernity.
\end{abstract}

Keywords: nation-building; official religion; Islam; national mosque; Islamist groups

\section{Introduction}

Forty-two states designate an official religion in their constitution. Of these, 25 states recognize Islam as the official religion, a category to which I refer as "officially-Islamic states." Of the 25 officially-Islamic states, all 25 have a large congregational mosque in their capital city. In all 25 cases, the mosque functions either officially or unofficially as the national mosque. Such mosques serve as a state space as a well as a religious space in their capacity as the staging ground for official religion. These mosques are where the head of state is filmed praying during national and religious holidays, and from which the Friday sermon is typically broadcast on state television. Being located in the capital city, national mosques are a physical reminder of the religious authority of the state in officially-Islamic contexts. Constructing a national mosque can be understood as a form of nation-building (Mylonas 2012), a means of visually signaling the Islamic character of the nation. All these states proclaim themselves Islamic, but most did not construct national mosques until after 1979. Why did mosque construction become an important part of being an Islamic state?

I argue that 1979 represents a critical juncture in political elites' views of Islam as a component of national identity, due to the heightened sense of threat posed by Islamist activists. Islamist activists are defined as individuals interested in making Islam more central to public life. Following the events of 1979, political elites viewed Islamist activists with greater trepidation, and sought to consolidate regime control over the religious sphere by signaling the Islamic character of the nation through the construction of a national mosque. The continued popularity of 
Islamist groups throughout the 1980s and 1990s, and the events of September 11, 2001, reinforced political elites' anxieties about Islamist activists, and the need to assert the religious authority of the state, and the Islamic identity of the nation.

In addition to diffuse anxieties about the danger posed by Islamist activists, over time the proliferation of national mosques increased the incentive for their construction. The combination of widespread concerns about Islamist activists, and the increasing ubiquity of national mosques, resulted in their construction in all 25 officially-Islamic states, as well as in many Muslimmajority states that do not designate Islam as the official religion. National mosque building constituted one of the methods deployed by political elites to define religion according to the terms of the state; however, it was not necessarily successful in bolstering the elites' religious authority.

This article draws on an original data set regarding the timing of mosque construction in all 25 officially-Islamic states. (Note that Jordan constructed two mosques: one completed in 1989 and one in 2005, for a total of 26 national mosques in the study.) One of the key contributions is to engage in medium $N$ analysis to demonstrate the increase in national mosque construction after 1979. In addition to the medium $N$ analysis of the 25 officially-Islamic states, case studies of three countries allow for more detailed causal process observation (Bennett and Elman 2006, Collier 2011). In these three cases, I use process tracing, participant observation, and interviews to examine views of the national mosques in each context.

Scholarship on nation-building would expect that in states whose authority is legitimated through Islamic principles, as signaled by the designation of Islam as the official religion, national mosque construction would occur soon after achieving independence in order to consolidate a unified national identity among the population and ensure political stability. However, in most of the officially-Islamic states, national mosques were built decades after independence. The increase in mosque building that occurred after 1979 was the result of factors associated with a post-1979 context, rather than with nation-building that took place soon after independence. Prior to 1979, only nine officially-Islamic states had a national mosque. By 2010, all 25 officiallyIslamic states had built or designated a national mosque (see Table 1).

The post-1979 context witnessed a shift in the conception of national identity put forward by the state. By trying to reassert the state's religious authority by constructing a national mosque, political elites contribute to the salience of Islam in the national identity (Cesari 2014, Connolly 1999, Hibbard 2010). Although national mosque construction was not seen as a key signal of national identity in most officially-Islamic states following independence, the eventual ubiquity of such mosques among these states indicates that national mosques are now seen as a necessary marker of Islamic character.

This holds true even among Muslim-majority states that are not officially-Islamic, such as the Muslim successor states of the USSR (Adams 2010, Koch 2016) and Turkey (Batuman 2016, Rizvi 2015). The pre-1979 construction of national mosques in states that are not officiallyIslamic, such as Indonesia, contributed to the view that a large national mosque represents an important signal of a nation's Islamic character. However, I do not extend my analysis to all states that have constructed an impressive national mosque because my argument is based on the role of Islam as established by the constitution. By having Islam as the official religion, regimes are more vulnerable to Islamists' accusations of insufficient commitment to Islam. Pressure from Islamists may have contributed to the construction of national mosques in these other contexts, but the official designation of Islam in the constitution is significant, and cases outside this scope condition would be best examined in future research.

The argument has implications for nationalism studies, especially those that focus on the use of space and structure to express national identity. Many such studies have highlighted the expression of national identity through modernist aesthetics in capital city architecture and urban planning (Bourdieu 1989, Cummings 2010, Minkenberg 2014, Rapoport 1993, Vale 1992). The association between modern architecture and nationalism is partly tied to assumptions that 
Table 1. Officially-Islamic States and National Mosques by Year of Construction.

\begin{tabular}{|c|c|c|c|c|}
\hline Year Built/Renovated & Year of Independence & Name of Mosque & Officially-Islamic State & Mosque Locations \\
\hline 731 & 1956 & Zaytuna & Tunisia & Tunis \\
\hline 972 & 1922 & Al Azhar & Egypt & Cairo \\
\hline 1472 & 1974 & Badjanani & Comoros & Moroni \\
\hline 1906 & 1977 & Hamoudi & Djibouti & Djibouti \\
\hline 1958 & 1984 & Sultan Omar Saifuddin & Brunei & Bandar \\
\hline 1965 & 1943 & Mesjid Nagara & Malaysia & Kuala Lumpur \\
\hline 1968 & 1971 & Baitul Mukharam & Bangladesh & Dhaka \\
\hline 1965 & 1919 & Pul-e Khishti & Afghanistan & Kabul \\
\hline 1970 & 1951 & Jamal Abdel Nasser & Libya & Tripoli \\
\hline 1984 & 1965 & As Sultan Mohamed & Maldives & Male \\
\hline 1985 & 1960 & Mosque Saudique & Mauritania & Noakchott \\
\hline 1986 & 1947 & Shah Faisal & Pakistan & Islamabad \\
\hline 1986 & 1961 & Mesjid al-dawla & Kuwait & Kuwait City \\
\hline 1987 & 1960 & Islamic Solidarity & Somalia & Mogadishu \\
\hline 1987 & 1971 & Al Fateh & Bahrain & Manama \\
\hline 1989 & 1946 & King Abdallah I & Jordan & Amman \\
\hline 1993 & 1956 & King Hassan II & Morocco & Casablanca** $^{\star \star}$ \\
\hline $1995^{\star}$ & 1979 & Imam Khomeini & Iran & Tehran \\
\hline 2001 & 1932 & Umm al Qura & Iraq & Baghdad \\
\hline 2001 & 1971 & Sultan Qaboos & Oman & Muscat \\
\hline 2005 & 1946 & King Hussein & Jordan & Amman \\
\hline $2006^{\star}$ & 1962 & Jami3 al-jaza'ir & Algeria & Algiers \\
\hline 2007 & 1971 & Sheikh Zayed & UAE & Abu Dhabi \\
\hline 2007 & 1932 & Mesjid al Haram & Saudi Arabia & 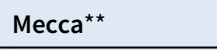 \\
\hline 2008 & 1967 & Saleh & Yemen & Sana'a \\
\hline 2011 & 1971 & Abdulwahhab & Qatar & Doha \\
\hline
\end{tabular}

Bold indicates mosques built after 1979; *, the year the mosque was begun, as it remains under construction; ${ }^{\star \star}$, Designates a city other than the capital city.

view nationalism as a result of modernization, specifically mass industrialization (Gellner 1983), print capitalism (Anderson 1983), and direct rule (Hechter 2000). Theories linking both modernization and nationalism with secularization have often based their conclusions on the forms of nationalism that emerged in the European context. In contrast, the construction of large religious structures such as national mosques expresses an alternative vision of modernity, one grounded in Islam, which has been overlooked because it does not take the expected secular modernist form. 


\section{Alternative Explanations and Case Selection}

Several possible alternative explanations emerge for the rise in national mosque building. One plausible alternative is the increase in oil wealth in many officially-Islamic states. The oil boom of the 1970s and 1980s could explain the construction of national mosques; in particular, their geographic concentration in the Middle East. However, several regimes constructed national mosques after 1979 without access to significant oil revenues: the Maldives, Morocco, Jordan, and Yemen. I examine two of these countries as case studies in order to understand why regimes with little access to capital would choose to invest their limited resources in such a costly project as building a national mosque.

An additional alternative explanation would be the leader's desire for self-aggrandizement: in six countries, the leader named the national mosque he constructed after himself: Djibouti, Brunei, Morocco, Oman, the United Arab Emirates (UAE), and Yemen. Note that in Brunei, Oman, and the UAE, the leader who constructed the mosque is also considered the "founder" of the modern state, or at least worked to construct this narrative. Table 2 presents the names selected for national mosques. I provide the meaning of the name of the mosque, or explain that the mosque's name refers to the person responsible for its construction ("Name of builder"), and specify if that individual is also seen as a founder of the state ("National founder/builder"), or if the builder named it after a founding father or figure of national significance ("National founder"/“National leader").

While self-aggrandizement likely played a role in national mosque construction, the majority of national mosques are not named after the individual responsible for building them. In 13 countries, the name of the national mosque refers to the founder of the nation, or a key national figure, or is named simply "the national mosque" or "the state mosque." I interpret names that refer to an individual of national significance or names such as "national mosque" as an indication that the mosque is meant as a national symbol.

An additional alternative explanation would be emulation effects: as more regimes chose to construct a national mosque, others followed suit. I consider emulation effects to have played a role in the widespread pattern of national mosque building, but given that most national mosques were built after the rise in the perceived threat of Islamists that followed 1979, emulation effects alone appear insufficient to explain the increase in national mosque construction.

In considering possible case studies, I looked for countries distributed across the Middle East and North Africa (MENA) region that had different colonial experiences in order to demonstrate that the patterns observed were not limited only to a single geographic area or colonial legacy. I selected contexts where the Islamist threat was less pronounced. If regimes react to Islamist pressure in contexts where they presented less of a threat, this offers stronger evidence for the influence of Islamist accusations of regime impiety. Monarchies are such contexts because the central government did not face the same threat to its religious legitimacy as the Arab republics that had promised radical social change and had claimed to embrace Western forms of secular representative government (Dekmejian 1980, Thomas 2005), and were thus more vulnerable to Islamist critiques that the government lacked both performance legitimacy and religious authority. Although the Arab monarchies had nonrevolutionary status (Davidson 2013) and did not claim to embrace secularism, they as a result were less threatened by Islamists' claims of authority on the basis of religious legitimacy.

The fact that the rulers of these monarchies-all of whom enjoyed a measure of religious legitimacy-felt compelled to build national mosques speaks to the threat posed by Islamists even in these contexts. I draw on secondary literature about the domestic circumstances that surround the building of national mosques in these cases, as well as participant observation and interviews at national mosques in Jordan, Oman, and Morocco. The findings are further informed by additional participant observation at national mosques in five other officially-Islamic states in the MENA region between 2009 and 2015: Egypt, Syria, Qatar, the UAE, and Yemen. 
Table 2. Officially-Islamic States, Name of Mosques, and Meaning of Mosque Name.

\begin{tabular}{|c|c|c|}
\hline Officially-Islamic State & Name of Mosque & Meaning of Name/Reference \\
\hline Tunisia & Zaytuna & "Olive" \\
\hline Egypt & Al Azhar & “The Most Resplendent" \\
\hline Comoros & Badjanani & "Call One Another" \\
\hline Djibouti & Hamoudi & Name of builder \\
\hline Brunei & Sultan Omar Saifuddin & Name of founder/builder \\
\hline Malaysia & Mesjid Nagara & "National Mosque" \\
\hline Bangladesh & Baitul Mukharam & "Sacred House" \\
\hline Afghanistan & Pul-e Khishti & "Brick bridge" (location) \\
\hline Libya & Jamal Abdel Nasser & Friend/mentor to builder \\
\hline Maldives & As Sultan Mohamed & National founder \\
\hline Mauritania & Mosque Saudique & Funded by Saudi Arabia \\
\hline Pakistan & Shah Faisal & Funded by Saudi Arabia \\
\hline Kuwait & Mesjid al-dawla & Grand State Mosque \\
\hline Somalia & Islamic Solidarity & Funded by Saudi Arabia \\
\hline Bahrain & Al Fateh & National founder \\
\hline Jordan & King Abdallah I & National founder \\
\hline Morocco & King Hassan II & Name of builder \\
\hline Iran & Imam Khomeini & National founder \\
\hline Iraq & Umm al Qura & "Mother of Battles" \\
\hline Oman & Sultan Qaboos & National founder/builder \\
\hline Jordan & King Hussein & National leader \\
\hline Algeria & Jami3 al-jaza'ir & National mosque \\
\hline UAE & Sheikh Zayed & National founder/builder \\
\hline Saudi Arabia & Mesjid al Haram & "Sacred Mosque" \\
\hline Yemen & Saleh & Name of builder \\
\hline Qatar & Abdulwahhab & Religious figure \\
\hline
\end{tabular}

Bold indicates mosques built after 1979.

Most cases for the study are national mosques built by officially-Islamic states, defined as a state that designates Islam as the official religion in the constitution. In officially-Islamic states, the production of religious discourse is viewed as an important task carried out by state institutions, such as by the Ministry of Religious Affairs.

Not all of the mosques in the study are officially designated as the national mosque. I include a mosque in the category of national mosque if it functions as one. In officially-Islamic states, the central government typically produces official religious content to be aired on state TV. Footage of the head of state praying on religious or national holidays, and footage of Friday sermons, are both examples of such content, which is produced in state-controlled religious spaces, typically in 
the large central mosque in the capital city. If there is a large mosque in the capital city that was built or renovated by the state and is featured on state TV, or on other state media including postage or currency, it serves as the symbol and staging ground for official Islam, and it functions as the de facto national mosque. In many cases, these mosques are recognizable for their grandiose architecture, for featuring an architectural style or material that is viewed as authentic to national heritage. In contrast, some national mosques are criticized for not representing local styles, revealing the assumption that their aesthetics should reflect national heritage, further affirming their status as symbols of the national identity. ${ }^{1}$ The use of national mosques as an analytical category may be useful for future studies of religious forms of nationbuilding.

To clarify, central governments also construct many state mosques in addition to the national mosque. Furthermore, most mosque building is undertaken by private individuals or communities, and not by the state. The Ministry of Religious Affairs regulates privately built mosques as well as state mosques, and can grant or withhold permission for mosque construction. In particularly populous or large states, there are often more informal mosques and places of religious gathering than a Ministry of Religious Affairs is able to oversee. Such conditions are relevant for considering when the central government may be motivated to reassert itself as the nation's preeminent religious authority, such as by constructing a national mosque.

Muslim majority states where Islam is not designated as the official religion in the constitution, such as Turkey and Indonesia, are outside the scope conditions for this inquiry. Existing research has considered the use of religion by nation-builders in Muslim majority states that are not officially-Islamic (Aslan 2014, Batuman 2016, Fabbe 2013, Porter 2002), and future research could consider the influence of Islamist groups on mosque construction in such contexts.

\section{Existing Literature: National Identity, Islam, and Mosque Building}

Scholars have identified various nation-building strategies employed by political elites, such as centralizing transportation and communication networks (Weber 1976), nationalist military training (Posen 1993), and including nationalist content in textbooks (Darden and Gryzmala-Busse 2006). Scholars have also demonstrated how Islam has been used to serve the project of nation-building in officially-Islamic states (Aktürk 2015, Asad 2009, Ayoob 2007, Cesari 2014, Eickelman and Piscatori 1996, Nasr 2001), and recent scholarship has examined the interplay between Muslim identity, state power, and urban planning (Atia 2013, El-Kazaz and Mazur 2017, Koch 2016). However, many of these insights pertain specifically to the MENA region, while more theoretical work on the relationship between religion and nationalism (Brubaker 2012, Friedland 2002) often fails to consider Islamic cases, as well as the strategic use of physical space. Alternatively, some works focused on nationalism and religion are primarily motivated to explain acts of violence (Juergensmeyer 1993, Pape 2005), a perspective that can be limiting.

The argument builds on scholarship that has studied how and when political elites articulate shifts in the content of national identity (Aktürk 2013, Shelef 2010), acknowledging that although nation-builders would prefer that their narratives appear timeless, politics can require a shift, as in the decision to emphasize a nation's Islamic character. I draw on studies of the use of monumental architecture to signify national values (Adams 2010, Bozdoğan 2015, King 1993, Rapoport 1993, Vale 1992). However, much work in this vein has focused on architectural glorifications of a vision of modernity that usually emphasized the power of the state and not the power of faith (Lefebvre 1991). High modernist architect Le Corbusier, and architects inspired by him, designed cities like Chandigarh and Brasilia based on the belief that technology and design, harnessed by the state, could improve human life (Scott 1998). Yet, less attention has been paid to religious structures as presenting alternative visions of the power of the modern state, in part 
because religion was typically seen as incompatible with the modern state, which was assumed to be secular.

National mosques have not typically been studied as a category. Instead analysis has tended to focus on a single national mosque as a case study (Baram 2014, Rogan 1986, Wainscott 2017) with a few notable exceptions (Hassner 2009; Koch, Valiyev, and Zaini 2017; Rizvi 2015). Mosques, within the broader category of gathering places, received some attention in the wake of the Arab Spring protests as scholars emphasized the importance of appropriate physical space in overcoming collective action problems (Butt 2016, Schwedler 2013) as well as how regimes often responded to mass collective action by destroying the spaces in which it had occurred (Ehsani 2014, Hasso and Salime 2016).

When a newly independent state established Islam as the official religion, some states already possessed a mosque that could serve as the staging ground of official religion, such as Egypt's Al Azhar and Tunisia's Al Zaytuna, both ancient and esteemed centers of Islamic religious authority. However, most newly independent states lacked an existing prestigious religious institution, and so chose to construct or designate a national mosque to represent the state's religious authority. However, the timing for when they chose to do so reflects variation in when nation-builders felt compelled to emphasize the Islamic identity of the nation.

\section{Islamist Challenges to the Religious Authority of the State}

Scholars have emphasized the significance of 1979 as a key turning point for politics in many Muslim-majority contexts. The overthrow of the Shah of Iran and the establishment of the Islamic Republic are often cited as events that demonstrated the transformative power of Islamism and caused many ruling regimes in the MENA to view Islamist activists as a potential threat (Antoun and Hegland 1987, Asad 1993, Dekmejian 1980, Eickelman and Piscatori 1996, Philpott 2009). Later that year, the seizure of the Mecca Grand Mosque by Islamist insurgents demanding the overthrow of the House of Saud reinforced the danger Islamists could pose to rulers (Esposito 1984, Dekmejian 1994, Okruhlik 2005). The events of 1979 have been interpreted as precipitating regimes' strenuous suppression of Islamist activism, while shifting toward more religiously oriented rhetoric and policies (Cesari 2014, Hibbard 2010, Zeghal 2008, Zubaida 1989). I propose an additional policy response that has been largely overlooked: the state-led construction of a large mosque in the capital city as an embodiment a national Islamic identity.

The post-1979 context was characterized by greater urgency on the part of governments to stake out a space for their religious authority. Across much of the MENA region, in the mid-20th century central governments felt primarily threatened by Leftist organizations' calls for radical social change. In the 1950s and 1960s, many political elites feared the widespread popularity of Egypt's Gamal Abdel Nasser and his call for Arab unity, which threatened both their power and their national sovereignty. Ruling regimes moved to curtail the influence of pro-Nasserist Leftist groups by empowering Islamist groups like the Muslim Brotherhood, under the assumption that Islamists, and a more pious society in general, would be less politically active than a society inspired by Leftist agitators (Al-Arian 2014, Masoud 2014).

Pressure from Islamists correlated with increasingly visible manifestations of Islamic piety in the late twentieth century, indicated by greater prevalence of hijab (veiling) among women, local mosque construction, and a rise in a demand for visas for pilgrimage to Mecca that exceeds that expected through population growth. The so-called "Islamic Awakening" has been acknowledged by many MENA specialists, although recent scholarship has critiqued the view that the persistent or resurgent salience of Islam was surprising, an assumption based on the secularization thesis, and instead has asserted that Islam did not become more salient, only more visible and political (Brown 2016, Cesari 2014).

In the following sections, I focus on three cases of national mosques built after 1979 in response to the perceived threat posed by Islamists to the state's religious authority. I analyze 
mosque construction in three monarchies: Jordan's King Abdullah I Mosque and King Hussein Mosque, completed in 1989 and 2005, respectively; Morocco's King Hassan II Mosque, completed in 1993; and Oman's Sultan Qaboos Grand Mosque, completed in 2001. I visited the King Hassan II Mosque in 2016 and the Sultan Qaboos Grand Mosque and Kings Abdullah and Hussein Mosques in 2015. Participant observation in these and other national mosques, as well as interviews, allow me to observe state practices in the staging ground of official religion. In these sections, I focus on the consequences of national mosque construction, and seek to evaluate the extent to which national mosques serve to bolster the regime's religious authority.

\section{Jordan: King Abdullah I Mosque and King Hussein Mosque, Amman}

In Jordan, the threat posed by Islamists to the rulers' religious authority was significant enough that the state built one national mosque, and then built a second that replaced the first. Scholars have noted that nation-building efforts in Jordan have been challenged by frequent demographic and territorial shifts (Lynch 1999) that have contributed to a form of so-called "fuzzy" nationalism (Frisch 2002). In addition, the lack of an existing set of premodern religious institutions in the territory of Jordan, later exacerbated by the absence of urban planning coupled with incautious destruction of old buildings in order to accommodate new residents in Amman, caused an identity crisis that prompted efforts to "Islamize" the appearance of the capital city (Rogan 1986). In Jordan, where historical markers of religion were sparse and the religious legacy of the capital city was insubstantial, the ruling regime decided to construct not one but two national mosques in the capital city, to signal their commitment to Jordan's Islamic identity.

The year 1979 represents one of the key turning points in the Jordanian regime's relationship to Islam and Islamists, as occurred across much of the region. Islamist expert Hassan Abu Hanieh emphasized this date as significant, "I was a Leftist in the 1970s. The role of Islam was weak then, the Islamists were the minority. But in the 70 s and 80 s after ' 79 Iranian Revolution, Islam became more prominent." " Many interviewees in Jordan stressed that Iran came to be seen as a threat after 1979 .

Relatedly, Islamist groups that were once viewed as harmless came to be seen as problematic. A leading member of the Islamic Action Front, the political wing of the Muslim Brotherhood in Jordan, explained the shift that had occurred in the level of state control of the religious sphere: "Today in Jordan the state controls everything. The state controls religious endowments, when originally religious endowments should be independent. The state controls the mosques, they cannot teach except with the agreement of the state." ${ }^{3}$ The Muslim Brotherhood in Jordan was once seen as a loyal opposition, however as the perceived threat from Islamists increased, the Jordanian government has sought to repress the group.

The regime tried to stress its Islamic credentials by building two national mosques. King Hussein built the King Abdullah mosque in downtown Amman in honor of his grandfather Abdullah, the founder of Jordan. Buoyed with funds from the Gulf monarchies that followed the war against Israel in 1973, he implemented subsidies, and simultaneously set out to solidify the religious authority of Hashemite rule, including with the construction of the mosque. The King Abdullah Mosque is depicted on the logo for the Ministry of Religious Affairs, and on the 20-dinar note.

Yet, in 2005 Hussein's son King Abdullah II constructed the King Hussein Mosque in honor of his father's memory, which took the role of national mosque from the mosque his father built. Located outside central Amman near the wealthy neighborhood of Dabuq, the new national mosque is larger, and is allegedly built in a traditional Jordanian style reminiscent of the aesthetic of the Ummayad Empire. Official state broadcasts of religious occasions, including the weekly Friday sermon, are recorded within this mosque.

After observing the success of the Islamic Revolution in Iran, as well as the assassination of Egyptian President Anwar Sadat in 1981, certain Islamists in Jordan embraced the potential for 
revolutionary Islamism, which included the overthrow of the Jordanian monarchy (Abu Rumman and Abu Hanieh 2013, 20). As Islamists emerged as a greater potential threat, political elites worked to curtail the influence of both the Muslim Brotherhood as well as the Salafists (Wiktorowicz 1999). Due to his British mother, Queen Muna (previously Toni Gardiner), and his early discomfort with Arabic, King Abdullah II faced a particular challenge in asserting his identity as an Arab and Muslim. His decision to construct a second national mosque constitutes one aspect of his ongoing efforts to solidify his identity and authority as an Islamic and Arab ruler.

In Jordan, the King Hussein National Mosque is viewed primarily as an attraction. Following the Friday sermon at the National Mosque in Amman in July 2015, interviews with mosquegoers reveal that many were visitors from other towns or even countries, who wished to visit the mosque as an attraction. According to one female mosque-goer visiting from Irbid, she and her family were in Amman to see family and decided to attend the sermon at the National Mosque in order to view the beautiful interior and appreciate the surrounding gardens. Two male mosquegoers from Yemen said they had heard about the National Mosque and wanted to see it for themselves. Of the five female and five male mosque-goers interviewed, only one interviewee lived nearby and regularly attended Friday sermon at the National Mosque. ${ }^{4}$ Mosque-goers' responses indicate that the King Hussein National Mosque functions to some extent as a touristic attraction. National Mosque attendants required all mosque-goers to leave the grounds almost immediately after the end of the sermon. Such measures are intended to reduce the possibility for Islamist activists to use mosque spaces to recruit other individuals to their cause.

In the case of Jordan, the investment of limited resources in two national mosques indicates the importance the regime places on signaling its commitment to the nation's national identity. Despite the construction of two national mosques, the religious authority of the Hashemite regime was not particularly enhanced, however the objective of manifesting the state's religious authority in the form of a national mosque was achieved.

\section{Morocco: King Hassan II Mosque, Casablanca}

The case of Morocco reinforces 1979 as significant to the regime's perception of Islamists and the need to assert its commitment to the nation's Islamic identity. Morocco was periodically ruled by Shi'a leaders, including Idris, the founder of the nation and a descendent of the Prophet Mohamed. However, after 1979, the regime began to emphasize its Sunni identity and discriminate against Shi'a inhabitants. Iran and Shi'a Islam remain bugbears of official Moroccan Islamic discourse. A representative of the US embassy in Rabat pointed out that the Shi'a are viewed as a "fifth column for Iran," a shift that followed the Iranian Revolution. ${ }^{5}$ The timing of the construction of the National Mosque corresponds to the increased sense of an Islamist threat following 1979.

Although King Hassan II announced his intention to build a mosque in Casablanca in 1968, construction only began in 1986. The Hassan II National Mosque was completed in 1993, and at the time boasted the tallest minaret in the world, and was second in size only to the Great Mosque of Mecca. The building's form was supposed to reflect traditional Moroccan heritage as well as replicate the great mosques of Islamic civilization. According to the Ministry of Cultural Affairs, the mosque typifies the "Hassanian" form of architecture, also found, for example, in the tomb of Mohamed V in Rabat. Hassanian architecture is described as "a ritual replication of architectonic 'artifacts' that contain centuries of memories of the Moroccan people, memories that represent the king as the only possible glue that can bind together the society's past, present, and future" (Elleh 2002, 112). Built almost exclusively with Moroccan materials, the mosque was financed by Moroccans. Following a TV appearance of the King himself in 1986, Moroccans were coaxed into contributing to a forty-day subscription drive that ultimately went on for five years; the total cost of construction was approximately 600 million USD. This evidence all reinforces 
the efforts made by the regime to cement the mosque's status as embodying Moroccan national identity, from its materials to its financing by ordinary if sometimes begrudging Moroccans.

King Hassan II selected Casablanca, the most populous and economically important city in Morocco, rather than the capital of Rabat. According to King Hassan himself, his choice of Casablanca was based on a Quranic verse that stated, "the throne of God is on the water" (The Quran, chapter 11 [Al-Hud], verse 7). The explanation for why Hassan II chose Casablanca rather than Rabat relates to earlier reasons identified for why rulers choose to expend significant resources to construct opulent national mosques in the first place: in order to erect a visual representation of the regime's symbolic and religious authority in a central and strategic location. In the case of Morocco, the vast numbers of people inhabiting the slums and suburbs of Casablanca represented a greater potential threat to the king's authority than that posed by the inhabitants of the sleepy administrative capital city, as demonstrated by the massive Casablanca riots of 1965 (Wainscott 2017). These posed a major challenge to Hassan's rule, to which he responded with the années de plomb (years of lead), a period known for the brutal suppression of opposition. In 1981, massive bread riots in Casablanca were forcefully put down and hundreds of protestors were killed. No such unrest occurred in Rabat. Casablanca needed a visual reminder of the king's spiritual and temporal authority.

Hassan had already established Rabat as the bureaucratic center of official Islam. In order to undermine the authority of the 'ulama (religious scholars) of Fez, Morocco's traditional spiritual center, King Hassan built a religious bureaucracy in his capital city of Rabat. Historically the ancient and esteemed mosque and university Al Qarawiyyin served to train Moroccan religious scholars. However, King Hassan required that any would-be cleric receive training at the state's official religious institution in Rabat, the Dar-al Hadith al-Hassania (Eickelman 1985, Feuer 2016). Simultaneously, he gutted the funding for Al Qarawiyyin. Stripped of prestige and resources, the 'ulama of Fez could no longer challenge his religious authority.

Constructing the second largest mosque in the world required a vast number of laborers and artisans, a boon to Casablanca's overpopulated and underemployed population. The addition of a giant attractive landmark drew tourists, who otherwise skipped Casablanca in favor of the UNESCO heritage sites found in Marrakesh, Fez, Meknes, and Rabat. By providing millions of Casablancans with temporary employment and a long-term source of tourist revenue, they would be less susceptible to the messaging of the political opposition, which was dominated by Islamists (Combs-Schilling 1999, Wainscott 2017). Building a mosque in Casablanca asserted the king's religious authority over his largest city, a motivation that similarly inspired mosque building in contexts where the largest city and the capital city were one and the same.

In addition to the real potential for unrest in Casablanca, Morocco's long-held status as a political entity made it less imperative to locate authority in Rabat. The capital of Morocco had shifted many times, but according to historical evidence and the official national narrative, the entity of Morocco itself had remained intact since the founding of the Idrisid dynasty during the 8th century. Although the Hashemites of Jordan had to establish a polity and identity for a territory that had never previously imagined itself as a single national community, Hassan II could rely on the historical narrative of a centuries-old Moroccan identity.

Given its precarious construction over the sea, upkeep of the mosque is expensive, but there was no provision made for maintenance funds. Bitterness at the expense imposed on the population is still strong. In interviews with Moroccan university students about Morocco's religious heritage, the topic of King Hassan arose organically. In discussing the former monarch, many students expressed umbrage at having had to pay for the monument, despite the fact that the mosque was completed before they were born. ${ }^{6}$ Their unsolicited comments speak to persistent frustrations about the ruler's insistence that the population fund his pet project.

In 1993, Hassan II threw a lavish ceremony to open the mosque, attended by religious and political notables from all over the country, thousands of men all clothed in white like the king himself. The ceremony had many similarities to one thrown by Sultan Mansur in 1593, exactly 
four hundred years earlier, intended to cement the ruler's religious authority (Combs-Schilling 1996). The ceremony was depicted on national television as a spectacle of national unity, embodied by the king. Hassan II achieved his objective of cementing his spiritual authority. When the regime first allowed Islamist political participation in the elections of 1997, Islamists knew that any challenge to the king's religious authority would be tantamount to heresy (Spiegel $2015,49)$. The only Islamist to challenge his religious stature was the head of the influential Islamist movement "Justice and Spirituality" (Al-Adl wa al-Ihsan), Abdessalam Yassine. In 1974 Yassine sent Hassan II a letter entitled "Islam or the Flood," in which he argues that a legitimate ruler must be chosen by the "ulama (Miller 2013). Yassine was not punished as a criminal, but instead locked in an insane asylum for three years, a demonstration that an anti-monarchical position was an expression of psychosis.

The King Hassan II Mosque is an example of how efforts by the head of state to assert his religious authority through the construction of an imposing visual reminder may not necessarily enhance the ruler's popularity. Yet, despite frustrations with the expense, King Hassan bequeathed an inheritance of religious authority to his son and successor King Mohamed VI, which opposition activists largely refrain from questioning publicly. Like his father, King Mohamed VI holds the title of "commander of the faithful" (amir al-mumineen), a moniker that King Hassan II inserted into the constitution 1962, which affirmed the preeminence of his political and religious authority that he subsequently sought to manifest in physical form with his eponymous mosque.

\section{Oman: Sultan Qaboos Grand Mosque, Muscat}

The Omani case offers an example of nation-building in the face of an Islamist threat that predated 1979, but that did not take the form of national mosque construction until after 1979. After coming to power in 1970, Sultan Qaboos combined the previously separate polities of Oman, historically ruled by an Ibadi imam and located in the interior, and Muscat, the historical domain of the sultans and sea-faring merchants. The official national narrative put forward by state institutions and curricula emphasized the similarities between these once separate entities, and deemphasized their historical separation and conflict, including the Jabal Akhdar War, which the two polities fought in the 1950s.

Sultan Qaboos avoided the ire of devout Ibadis by not claiming the status of an Ibadi imam, and instead prioritized the civic character of the multi-ethnic Omani nation. However, in addition to using oil rents to construct roads, schools, and hospitals for a population that until the 1970s had been largely illiterate and bereft of state services, Qaboos also built a Sultan Qaboos Mosque in every city and major town. This quietly undermined Ibadi doctrine, which stipulated that congregational prayer can only be led by the ruling Ibadi imam (Siegfried 2006). When Ibadi Omanis gather to pray on Friday, their presence signals either ignorance or rejection of the Ibadi injunction to only pray the congregational prayer when led by the ruling Ibadi imam.

Oman has garnered international attention for the fact that Ibadis and Sunnis pray together, a fact that the official narrative attributes to a history of Ibadi religious tolerance. ${ }^{7}$ However the practice of congregational prayer actually flouts Ibadi doctrine, as noted above. The fact that Ibadi Omani men, and some women, have embraced the Sunni practice of gathering for Friday prayer, is likely due to the presence of large, often air-conditioned state mosques, as well as the influence of Sunni religious programming on satellite TV channels. Qaboos, as well as exposure to the rest of the Muslim world, have both undermined the traditional Ibadi practice of only gathering for congregational prayer when led by the Ibadi imam.

The Sultan Qaboos Grand Mosque in the Bowshar neighborhood of Muscat serves as Oman's national mosque. The building's architecture and grounds emphasize an ecumenical form of Islam rather than a specifically Ibadi or Omani one. The ornamentation of the mosque explicitly highlights styles and contributions from all corners of the Islamic world, such as the style of the 
Andalucían caliphate in Spain, and the tile work of the Persian Sassanid Empire. The presence of a single minaret, as well as towers on the external wall, are out of keeping with Ibadi mosques, which traditionally lack a minaret and maintain a very simple structure. By emphasizing the artistic contributions of multiple Islamic traditions, the mosque is able to avoid thorny questions regarding its status as a specifically Ibadi mosque, opting instead for a universalistic approach to Islam.

The ecumenical intention appears confirmed by the speech given by Sultan Qaboos during the ceremonial inauguration of the mosque, where he notes that the mosque was intended to function as "a center of culture and thought that... would contribute to the revival of the Islamic heritage... and highlight the civilized values of the Muslim nation while modernizing its approach to dealing with Islamic affairs and issues" (Said 2010). Despite this vaunted rhetoric, some individuals avoid praying at the Sultan Qaboos Grand Mosque due to their belief that the space belongs to the state rather than God. ${ }^{8}$

The intention for the National Mosque to convey a non-sectarian form of Islam is corroborated by volunteers at the Sultan Qaboos Grand Mosque's Islamic Information Center, where non-Muslims are invited in for dates and Arabian coffee and encouraged to ask questions about Islam. The volunteers speak about Islam in general, rather than a specifically Omani form of Islam, although they are quick to highlight Sultan Qaboos' role in deemphasizing sectarianism. One senior volunteer expressed her views on the lack of sectarianism in Oman:

In Oman, you cannot talk about schools of thought, not Shia and Sunni, you can get into trouble with that. We have the schools of thought but we should all live in harmony together. In one Omani family, you could have an Ibadi father and Sunni mother and a daughter-in-law who is Shi'a. Due to the wonderful leadership, we enjoy peace. ${ }^{9}$

Her comments highlight the carefully constructed narrative that places Qaboos' leadership at the center of Omani peace and prosperity.

Prior to Qaboos' takeover of power from his father in 1970, conflict with Islamists flared in the Jabal Akhdar War of the 1950s, when the followers of the would-be Imam launched an armed rebellion to establish an Imamate in the interior of the country. Sultan Qaboos' father Sa'id put down the insurrection with the support of the British Royal Air Force, although the prospect of supporters of an Imamate trying to re-establish control remains seen as a threat.

Oman is an example of a context in which state elites engaged in nation-building, but before the late 1990s did not adopt the strategy of building a national mosque. Sultan Qaboos had constructed congregational mosques in many cities, despite the Ibadi injunction against congregational prayer in the absence of a ruling Ibadi imam. Yet, it was only after facing intensified pressure from Islamists that he chose to physically manifest his power and authority in the enormous Sultan Qaboos Grand Mosque in his capital city.

\section{Achievements and Outliers}

Have political elites achieved their goal of strengthening their religious authority with the construction of a national mosque? Interview evidence indicates not. In wealthy countries, efforts to build ever larger and more impressive mosques are largely symbolic, as many such grandiose mosques, especially in the Gulf countries, sit largely empty. People gather there for Friday prayer and for important religious holidays like Eid al-Fitr and Eid al-Adha, but rarely do they fill to capacity. Interviews reveal that for some, national mosques are not perceived as spiritual centers, but merely as important places to see and be seen, a place for conspicuous piety, but not true spiritual connection. ${ }^{10}$

In poorer contexts, expenditure on a grandiose national mosque may anger citizens, as in Morocco. In Yemen, President Saleh spent 60 million USD to construct a mosque in the capital city of Sana'a. Begun in 2001 and completed in 2008, the mosque was built largely using public 
funds, but also financed by wealthy businessmen strong-armed into contributing by Saleh's regime. Mosque goers voiced frustration that the president would spend lavishly on a huge and magnificent mosque when so many in the population still lacked basic necessities. ${ }^{11}$

Despite failing to significantly enhance their religious authority, political elites' objective may in fact have been achieved simply by building a space that conveys the Islamic character of the nation, a physical bulwark against Islamists' efforts to assert a monopoly over religious legitimacy. Similar to other structures built to symbolize the nation, their power often lies in the extent to which they are taken for granted. Although national mosques were once relatively uncommon, now it is assumed that a government would build a national mosque.

In three officially-Islamic states-Pakistan, Somalia, and Mauritania-the construction of a national mosque was funded by Saudi Arabia. Why a foreign government, and specifically Saudi Arabia, would pay to construct a national mosque in a foreign officially-Islamic state is related to questions of soft power, which are distinct from the nation-building imperative on which I focus. I count these three cases as supporting evidence because the central governments in question faced similar motivations as other officially-Islamic states-namely, pressure from Islamist activists-when agreeing to accept Saudi money to build the national mosque.

Relatedly, I include Saudi Arabia's massive renovations of the Mesjid al Haram in Mecca as an example of national mosque construction. The Mesjid al Haram, site of the Kabba, obviously predated the establishment of the Saudi kingdom. However, the scale of the changes to the site, including the addition of the massive Mecca Royal Clock Tower, the third tallest building in the world as well as the designation of the surrounding hotel complex as officially holy ground (Bsheer 2014), represent sufficient changes to the original mosque to constitute an effort by the House of Saud to remake the site in accordance with its own agenda. Because the House of Saud justifies its rule on the basis of strict adherence to Wahhabi Islam, Mecca is arguably more significantly symbolic than the capital city of Riyadh.

\section{Conclusion}

The article examines the empirical puzzle of why two-thirds of officially-Islamic states constructed a national mosque between 1979 and 2010. Although factors such as rulers' selfaggrandizement or economic incentives likely played a supporting role, they cannot account for the specific time period, and pressures associated with Islamist activists offer the best explanation for the increase in mosque construction after 1979. The geographic pattern of national mosque building outside the MENA region before 1979 and inside the MENA region after 1979 is consistent with expectations for Islamic nation-building in response to the rise in Islamists' popularity. The increase of national mosque construction ultimately made the practice ubiquitous among all officially-Islamic states, converting it into an important part of national identity. National mosques in these contexts represent a nation-building strategy to undermine the standing of Islamist groups by reclaiming physical, visual, and rhetorical religious space.

By constructing visual representations of the state's power over religion, political elites hoped to visually demonstrate their power and authority as well as undermine that of the Islamist opposition. The construction of a national mosque signals a shift in political elites' strategy of nation-building toward a greater emphasis on Islam in the public sphere and, specifically, as a component of the national identity.

Monumental architecture has long been associated with the projection of political power. In Muslim majority societies, political and economic elites often chose to demonstrate their prominence as well as their piety by constructing large congregational mosques. Similar to the construction of a cathedral, temple, or other grand religious structure in non-Muslim contexts, a large mosque could signify or elevate the importance of a given location. In the era of nationalism, the tradition of building monumental structures has often been used to glorify the nation. 
Architecture is frequently noteworthy in the national capital, as the institutions of government are typically housed in structures intended to evoke national pride. As empires transitioned to states, leaders often sought to dignify newly established capital cities using architecture.

Future scholarship could expand the scope of the inquiry beyond officially-Islamic states to evaluate how mosque building is used for Islamic nation-building in contexts like Turkey, Indonesia, or Kazakhstan. The findings offer guidance for considering how religious structures have been used by nation-builders to signal national identity in non-Muslim contexts that may have previously been overlooked due to the perceived association between secularism, modernity, and nationalism. Temples, churches, synagogues, and other religious structures built by the state can be fruitfully studied from a comparative perspective as emblems of nationbuilding.

A key contribution is establishing national mosques as an analytic category. Another contribution is the development of a theory for why these structures went from being relatively uncommon to ubiquitous among officially-Islamic states. The findings have implications for the conception of the nation in officially-Islamic contexts. In their efforts to assert their control over the religious sphere, political elites contributed to the salience of Islam as a component of the national identity. An unintended consequence of strengthening the Islamic content of national identity is the empowerment of the Islamist opposition actors that political elites set out to undermine.

Acknowledgements. Many thanks to Nathan Brown, Kristin Fabbe, Marc Lynch, and Harris Mylonas for their invaluable feedback in preparing the article, and to three anonymous reviewers for Nationalities Papers, whose insights strengthened the final piece.

Financial Support. The author acknowledges the financial support of a Travel Research Engagement (TRE) grant to Qatar and Oman in 2014, provided by the Project on Middle East Political Science (POMEPS), and a Foreign Language and Area Studies (FLAS) grant to Jordan in 2015, provided by the US Department of Education.

\section{Notes}

1 Author interview with female mosque-goer, Saleh Grand Mosque (Sana'a, Yemen, July 9, 2010, 1:00pm).

2 Author interview with Hassan Abu Hanieh (Amman, Jordan, July 29, 2015, 2:00pm).

3 Author interview with founder of Islamic Action Front, Interview ID 24A (Sahab, Jordan, August 17, 2015, 10:00am).

4 Author interview with 10 mosque-goers at the King Hussein National Mosque (Amman, Jordan, July 24, 2015, 1pm).

5 Author interview with diplomat at the US Embassy, Interview ID 7C (Rabat, Morocco, June 7, 2016, 12:30pm).

6 Author roundtable with the students of The Language Cafe, Interview ID 12C and 13C. (Rabat, Morocco, August 3, 2016, 6:30pm).

7 In an episode of his popular TV show "Khawatir" (Thoughts) that aired in June 2015, Saudi pop-cleric Ahmed al-Shugairi visited Oman to highlight the lack of sectarian tension, as demonstrated by the presence of Ibadis and Sunnis praying together in a mosque. https:// www.youtube.com/watch?v=7lXQDL-cyGk (accessed March 6, 2017).

8 Author interview with professor at Sultan Qaboos University. (Muscat, Oman, February 27, 2014, 3:30pm).

9 Author interview with volunteer at Sultan Qaboos Grand Mosque, Interview ID 1B (Muscat, Oman, October 29, 2015, 11:00am).

10 Author interview with female mosque attendant, Interview ID D3 (Abdulwahhab National mosque, Doha, Qatar, March 2014); Author interview with male mosque goer, Interview A4.5 (King Hussein National Mosque, Amman, Jordan, June 24, 2015); Author interview with professor, Interview B23 (Muscat, Oman, December 7, 2015).

11 Author interview with female mosque-goer, Saleh Grand Mosque (Sana'a, Yemen, July 9, 2010, 12:30pm). 


\section{References}

Abu Rumman, Mohammed and Hassan Abu Hanieh. 2013. The Islamic Solution in Jordan. Amman: Friedrich-EbertStiftung.

Adams, Laura. 2010. Spectacular State: Culture and National Identity in Uzbekistan. Durham, NC: Duke University Press. Al-Arian, Abdullah. 2014. Answering the Call: Popular Islamic Activism in Sadat's Egypt. New York: Oxford University Press.

Aktürk, Şener. 2013. Regimes of Ethnicity and Nationhood in Germany, Russia, and Turkey. New York: Cambridge University Press.

Aktürk, Şener. 2015. "Religion and Nationalism: Contradictions of Islamic Origins and Secular Nation-Building in Turkey, Algeria, and Pakistan.” Social Science Quarterly 96 (3): 778-806.

Anderson, Benedict. 1983. Imagined Communities. New York: Verso Publishers.

Antoun, Richard and Mary Hegland. 1987. Religious Resurgence: Contemporary Cases in Islam, Christianity, and Judaism. Syracuse, NY: Syracuse University Press.

Asad, Talal. (1986) 2009. “The Idea of an Anthropology of Islam.” Reprint, Qui Parle 17 (2): 1-30.

Asad, Talal. 1993. Genealogies of Religion: Discipline and Reasons of Power in Christianity and Islam. Baltimore, MD: Johns Hopkins University Press.

Aslan, Senem. 2014. Nation-building in Turkey and Morocco: Governing Kurdish and Berber Dissent. New York: Cambridge University Press.

Atia, Mona. 2013. Building a House in Heaven: Pious Neoliberalism and Islamic Charity in Egypt. Minneapolis, MN: University of Minnesota Press.

Ayoob, Mohammed. 2007. The Many Faces of Political Islam: Religion and Politics in the Muslim World. Ann Arbor, MI: University of Michigan Press.

Baram, Amatzia. 2014. Saddam Husayn and Islam, 1968-2003. Baltimore, MD: Johns Hopkins University Press.

Batuman, Bülent. 2016. "Architectural Mimicry and the Politics of Mosque Building: Negotiating Islam and Nation-building in Turkey." The Journal of Architecture 21 (3): 321-347.

Bennett, Andrew, and Colin Elman. 2006. "Complex Causal Relations and Case Study Methods: The Example of Path Dependence.” Political Analysis 14 (3): 250-267.

Bourdieu, Pierre. 1989. "Social Space and Symbolic Power." Sociological Theory 7 (1): 14-25.

Bozdoğan, Sibel. 2015. Modernism and Nation Building: Turkish Architectural Culture in the Early Republic. Seattle, WA: University of Washington Press.

Brown, Nathan. 2016. Arguing Islam After the Revival of Arab Politics. New York: Oxford University Press.

Brubaker, Rogers. 2012. "Religion and Nationalism: Four Approaches." Nations and Nationalism 18 (1): 2-20.

Bsheer, Rosie. 2014. "Making History, Remaking Place: Textbooks, Archives and Commemorative Spaces in Saudi Arabia." $\mathrm{PhD}$ diss., Columbia University.

Butt, Ahsan. 2016. "Street Power: Friday Prayers, Islamist Protests, and Islamization in Pakistan." Politics and Religion 9 (1): $1-28$.

Cesari, Jocelyne. 2014. The Awakening of Muslim Democracy: Religion, Modernity, and the State. New York: Cambridge University Press.

Collier, David. 2011. "Understanding Process Tracing.” PS: Political Science and Politics 44 (4): 823-830.

Combs-Schilling, Elaine. 1996. “Casablanca 1993: Negotiating Gender and Nation in Performative Space." Journal of Ritual Studies 10 (2): 1-35.

Combs-Schilling, Elaine. 1999. "Performing Monarchy, Staging Nation.” In In the Shadow of the Sultan: Culture, Power, and Politics in Morocco, edited by Rahma Bourqia and Susan G. Miller, 176-242. Cambridge, MA: Harvard University Press. Connolly, William. 1999. Why I Am Not a Secularist. Minneapolis: University of Minnesota Press.

Cummings, Sally. 2010. Symbolism and Power in Central Asia: Politics of the Spectacular. London: Routledge.

Darden, Keith. and Anna Gryzmala-Busse. 2006. “The Great Divide: Literacy, Nationalism, Communist Collapse.” World Politics, 59 (1): 83-115.

Davidson, Christopher. 2013. After the Sheikhs: The Coming Collapse of the Gulf Monarchies. New York: Oxford University Press.

Dekmejian, Hrair. 1980. "The Anatomy of Islamic Revival: Legitimacy Crisis, Ethnic Conflict and the Search for Islamic Alternatives." Middle East Journal 34 (1): 1-12.

Dekmejian, Hrair. 1994. "The Rise of Political Islamism in Saudi Arabia.” Middle East Journal 48 (4): 627-643.

Ehsani, Kaveh. 2014. "The Production and Politics of Public Space Radical Democratic Politics and Public Space." International Journal of Middle East Studies 46 (1): 159-162.

Eickelman, Dale. 1985. Knowledge and Power in Morocco: The Education of a Twentieth-Century Notable.Princeton, NJ: Princeton University Press.

Eickelman, Dale and James Piscatori. (1996) 2004. Muslim Politics. Princeton, NJ: Princeton University Press.

El-Kazaz, Sarah and Kevin Mazur. 2017. "Introduction to Special Section: The Unexceptional Middle Eastern City." City and Society 29 (1): 148-161.

Elleh, Nnamdi. 2002. Architecture and Power in Africa. Westport, CT: Praeger. 
Esposito, John. (1984) 1998. Islam and Politics. Syracuse, NY: Syracuse University Press.

Fabbe, Kristin. 2013. "Historical Legacies, Modern Conflicts: State Consolidation and Religious Pluralism in Greece and Turkey." Journal of Southeast European \& Black Sea Studies 13 (3): 435-453.

Feuer, Sarah. 2016. State Islam in the Battle Against Extremism: Emerging Trends in Morocco and Tunisia. Washington, DC: The Washington Institute for Near East Policy.

Friedland, Roger. 2002. "Money, Sex, and God: The Erotic Logic of Religious Nationalism." Sociological Theory 20 (3): $381-$ 425.

Frisch, John. 2002. "Fuzzy Nationalism: The Case of Jordan." Nationalism and Ethnic Politics 8 (4): 86-103.

Gellner, Ernest. 1983. Nations and Nationalism. Ithaca, NY: Cornell University Press.

Hassner, Ron. 2009. War on Sacred Grounds. Ithaca, NY: Cornell University Press.

Hasso, Frances and Zakia Salime, eds. 2016. Freedom Without Permission: Bodies and Space in the Arab Revolutions. Durham, NC: Duke University Press.

Hechter, Michael. 2000. Containing Nationalism. New York: Oxford University Press.

Hibbard, Scott. 2010. Religious Politics and Secular States: Egypt, India, and the US. Baltimore, MD: Johns Hopkins University Press.

Juergensmeyer, Mark. 1993. The New Cold War? Religious Nationalism Confronts the Secular State. Oakland, CA: University of California Press.

King, Anthony. 1993. "Cultural Hegemony and Capital Cities.” In Capital Cities/ Les Capitales: Perspectives Internationales/ International Perspectives, edited by John Taylor, Jean G. Lengellé and C. Andrew, 251-270. Ottawa: Carleton University Press.

Koch, Natalie. 2016. “The 'Personality Cult' Problematic: Personalism and Mosques Memorializing the 'Father of the Nation' in Turkmenistan and the UAE." Central Asian Affairs 3 (4): 330-359.

Koch, Natalie, Anar Valiyev, and Khairul Zaini. 2017. "Mosques as Monuments: An Inter-Asian Perspective on Monumentality and Religious Landscapes.” Cultural Geographies 25 (1): 1-17.

Lefebvre, Henri. 1991. The Production of Space, trans. Donald Nicholson-Smith. Oxford: Blackwell Publishers.

Lynch, Marc. 1999. State Interests and Public Spheres: The International Politics of Jordan's Identity. New York: Columbia University Press.

Masoud, Tarek. 2014. Counting Islam: Religion, Class, and Elections in Egypt. New York: Cambridge University Press.

Miller, Susan. 2013. A History of Modern Morocco. New York: Cambridge University Press.

Minkenberg, Michael. ed. 2014. Power and Architecture: The Construction of Capitals and the Politics of Space. New York: Berghahn Books.

Mylonas, Harris. 2012. The Politics of Nation-building: Making Co-Nationals, Refugees, and Minorities. New York: Cambridge University Press.

Nasr, Vali. 2001. Islamic Leviathan: Islam and the Making of State Power. New York: Oxford University Press.

Okruhlik, Gwenn. 2005. "The Irony of Islah (reform).” The Washington Quarterly, 28 (4): 153-170.

Pape, Robert. 2005. Dying to Win: The Strategic Logic of Suicide Terrorism. New York: Random House.

Philpott, Daniel. 2009. "Has the Study of Global Politics Found Religion?" Annual Review of Political Science 12: $183-202$.

Posen, Barry. 1993. "Nationalism, the Mass Army, and Military Power.” International Security 18 (2): 80-124.

Porter, Donald. 2002. Managing Politics and Islam in Indonesia. New York: RoutledgeCurzon.

Rapoport, Amos. 1993. "On the Nature of Capitals and their Physical Expression." In Capital Cities/ Les Capitales: Perspectives Internationales/ International Perspectives, edited by John Taylor, Jean G. Lengellé and Caroline Andrew, 3167. Ottawa: Carleton University Press.

Rizvi, Kishwar. 2015. The Transnational Mosque: Architecture and Historical Memory in the Contemporary Middle East. Chapel Hill: University of North Carolina Press.

Rogan, Eugene. 1986. "Physical Islamization of Amman." The Muslim World 76: 24-42.

Said, Qaboos bin. 2010. The Royal Speeches of His Majesty, Sultan Qaboos bin Sa'id: 1970-2010. Muscat: Oman Ministry of Information.

Schwedler, Jillian. 2013. "Spatial Dynamics of the Arab Uprisings." PS: Political Science and Politics 46 (2): $230-234$.

Scott, James. 1998. Seeing Like a State: How Certain Schemes to Improve the Human Condition Have Failed. New Haven, CT: Yale University Press.

Shelef, Nadav. 2010. Evolving Nationalism: Homeland, Identity, and Religion in Israel 1924-2005. Ithaca, NY: Cornell University Press.

Siegfried, Nicholas. 2006. "Legislation and Legitimation in Oman: The Basic Law," Islamic Law and Society 7 (3): $359-397$. Spiegel, Avi. 2015. Young Islam: The New Politics of Religion in Morocco and the Arab World. Princeton, NJ: Princeton University Press.

Thomas, Scott. 2005. The Global Resurgence of Religion and the Transformation of International Relations. New York: Palgrave Macmillan.

Vale, Lawrence. 1992. Architecture, Power, and National Identity. New Haven, CT: Yale University Press.

Wainscott, Ann. 2017. Bureaucratizing Islam: Morocco and the War on Terror. New York: Cambridge University Press. 
120 Annelle R. Sheline

Weber, Eugen. 1976. Peasants into Frenchmen: The Modernization of Rural France, 1870-1914. Stanford, CA: Stanford University Press.

Wiktorowicz, Quintan. 1999. “State Power and Regulation of Islam in Jordan.” The Journal of Church and State 41 (4): 677-696.

Zeghal, Malika. 2008. Trans. George Holoch. Islamism in Morocco: Religion, Authoritarianism, and Electoral Politics. Princeton, NJ: Markus Wiener Publishers.

Zubaida, Sami. [1989] 2009. Islam, the People and the State: Political Ideas and Movements in the Middle East. New York: I.B. Tauris.

Cite this article: Sheline, A. R. 2019. Constructing an Islamic Nation: National Mosque Building as a Form of NationBuilding. Nationalities Papers 47: 104-120, doi:10.1017/nps.2018.15 